\title{
Effects of Chinese Foreign Direct Investment in Africa
}

\author{
Roquia Fane Madouka Koumou*, Wang Manyi \\ Department of Finance, Capital University of Economics and Business, Beijing, China
}

Email address:

roquiamadouka@yahoo.fr (R. F. M. Koumou)

${ }^{*}$ Corresponding author

\section{To cite this article:}

Roquia Fane Madouka Koumou, Wang Manyi. Effects of Chinese Foreign Direct Investment in Africa. Journal of Finance and Accounting. Vol. 4, No. 3, 2016, pp. 131-139. doi: 10.11648/j.jfa.20160403.15

Received: March 21,2016; Accepted: April 29, 2016; Published: May 20, 2016

\begin{abstract}
Over the past twenty decades, countless studies both empirical and theoretical have attempted to study the effect of Foreign Direct Investments (FDI) on the economy. A great majority of these studies reached the conclusion that FDI accounts for technology transfer across countries, which in turn increases the total investment in the economy of the host countries. These studies seem also to suggest that FDI contribute relatively more to growth than domestic investment. However, with regard to studies about the Chinese investments in Africa, many authors claimed that Chinese investments in Africa bring more harm than good to the economy. They go even far to claiming that Chinese are predators of the African raw materials, and most authors remain very cautions when it comes to listing the positive effects of these investments. The goal of this paper was thus to weigh out effects (both negative and positive) of the Chinese investments in Africa. The conclusion drawn at the end of this investigation was that far from being all negative, Chinese investments are setting the African economy on the road to achieving economy development. This is because they allow African countries to go towards the modernization, industrialization and strong economic growth. It was however also observed that the claims as to which Chinese are predators of the African raw materials is slightly true. Furthermore, this hanger of raw materials leads to the closing of many local companies. Hence, it was concluded that the harmonization and the improvement of Chinese investments in Africa should pass by the respect for rules dictated by the governments (institutions) and the respect for the international standards.
\end{abstract}

Keywords: Foreign Direct Investment, Economic Growth, Trade, Africa, China

\section{Introduction}

The amazing growth ${ }^{1}$ of China and its capacity to get out of the underdevelopment within thirty years and to become both one of world emergent power, and the main exporter of manufactured goods draws the attention of numerous developing countries. For Africa, China is seen not only as a model of development but also a source of funding and exchanges beyond its traditional development partners (America and Europe). China is now equipped with a significant economic capacity and a foreground policy ambition, and has become a must-see in world geopolitics. To intend to stop China seems to be an impossible mission

1 China which was used to a $10 \%$ growth every year, since 2014 this growth is for the reduction, it is necessary expect at the moment approximately $5 \%$ in the year which come even a no or negative growth. and to ignore China would be even more serious, "i.e. it would be a dangerous political blindness" (Gaye Adama 2006). Because, since 1993 China became the largest recipient of Foreign Direct Investment (FDI) among emerging countries, with an increase of $70 \%$ over 2009 and exceeded over 50 billion dollar USD in 2015, while bilateral trade between the Chinese and Africa has exceeded more than 300 billion USD (According to the Standard Bank of South Africa). The report on investment in the world of the United Nations Conference on Trade and Development (UNCTAD) defines FDI as "an investment involving a longterm relationship and reflecting a purpose of interest and control of an entity resident of an economy (foreign direct investment or parent company) of a company which is resident in an economy other than that of the investor (affiliate corporate or subsidiary abroad)". Through direct investment that China receives from the rest of the world and 
capital that she squirts as well in the largest economy in the world (the United States) than in smaller economies (South Africa, Angola, Guinea, Niger, Sudan... etc.), it is now a model of economic success for many developing countries. Because Foreign Direct investment is considered today as a source of more employment (increase in demand of labor), vector of technology transfer and an engine of economic growth, China seems to succeed where many countries have failed. China can brag about its successful economic development. But beyond this economic success, the international policy of China leaves a feeling of a new approach towards foreign direct investment. The Western countries' approach to FDI is that FDI is viewed as a source of financing for economic growth for the recipient countries. The Chinese approach differs from that of Westerners in its relationship with the economic and political situation in recipient countries. While Western countries take into account the macro-economic and political situation in the location of their FDI in a given country, China as is simply indifferent to the domestic policies of host countries. Although China supports the political liberalization as an engine for development, it does not appear to share the ideal of political liberalization. Faithful to its logic, China does not intervene in domestic policies of her economic partners. This model of development that we described as non-interference in the domestic policies of other countries is also one of the pillars of China's foreign policy. Applied to its economic strategy in terms of FDI, the Chinese approach produces very visible results in developing countries, notably African countries.

In fact, the increase of the Chinese FDI in Africa was beneficial to both Africa and China in terms of economic development. Indeed the relations between China and Africa through political and financial support to a pragmatic economic cooperation, aiming at "the realization of mutual profits" (Zhibiao, on 2007; Prah, on 2007). For Chinese government, the economic relations developed between China and Africa is based on the "win-win" principle, in other words, it allows Chinese and African governments to benefit without harming each other. But many observers, notably Westerners are very critical about the slogan of the principle of "win-win" used by the Chinese authorities in their economic relations with African countries, for some their economic relations represent a form of neocolonialism.

However it should be noted that China has been present in Africa since the late $1950 \mathrm{~s}$, but with regard to the increase in foreign direct investment Chinese in Africa, is a recent phenomenon dating back in the 2000s with a sharp increase observable in most African countries. This is due to the creation in 2000 of the first forum on Sino-Africa cooperation (FOCAC), which became an important platform for dialogue between China and African countries, which is also an effective regime of pragmatic cooperation of the two sides. In other words, the Sino-African Forum in 2006 confirmed the central place of Africa in the outward strategies of the Chinese government, and particularly the creation of a fund for development of Africa endowed with 5 billion USD budget, the cancellations of debt for 1.4 billion USD concerning approximately 31 countries and in 2012 the budget of the aid reached more than 13 billion USD.

While there is a large amount of work that investigates the recent Intensification of Sino-Africa Economic Cooperation, there is no consensus shown concerning the real consequences or effects of China's investments in African countries.

Thus, the purpose of this paper is to provide an overview on the effects of the Chinese investment in Africa.

In order to understand the effects of Chinese FDI in Africa, the rest of this paper is structured as follows: the second section gives an overview of the presence of China in Africa in a historic context, the third section is to see how was the Chinese FDI in Africa by sector between 1979-2000 and to see Chinese FDI flows to Africa between 2003 - 2011, the fourth section provides an overview literature regarding the relationship between FDI and economic growth in Africa while, the fifth section presents the effects of Chinese FDI in Africa, and the sixth section it's the conclusion and future prospect.

\section{The Presence of China in Africa: $A$ Historical Perspective}

Historically, trade ties between China and Africa date back to emperors Han times in the second century BCE, like shown by the route of the Chinese navigator Zheng He, who reached the coast of Africa, and landed in Somalia and in Kenya at the beginning of the XVth century. However, this period of exploration was followed by several centuries of sidelines. It is with the establishment of the People's Republic of China, in 1949, and particularly after the conference of Bandung, that China was again interested in other developing countries. That conference tried to promote an economic and cultural cooperation between Africa and Asia and to organize an opposition to the colonialism. China also brought its support for the pro-independence movements in diverse country (Burma, Malaysia and Viet Nam) and an economic assistance in others (Mongolia, North Korea) (Richer, on 2008).

During the post-colonial period, China tried hard to spread its influence in other developing countries and to export the communist revolution. Countries which had just reached the independence considered that she offered a way other than the domination by the former colonial powers. So, China signed an agreement of economic and technical cooperation with Guinea in 1960, on one year after the independence of the latter. China then granted a 20 million dollars loan without interests to Ghana, first country of Africa to establish diplomatic relations with China. China also recognized Mali at the time of her independence and sent it a commercial mission next year. These three countries were politically close to China. However, the latter also entered into relationships with other countries, for example Algeria, Morocco and Tunisia in North Africa. China also signed an 
agreement of economic and technical cooperation with Algeria and lent him 50 million dollars in the 1950s, even if Algeria had not given up its relations with Soviet Union.

The Sino-African relations remained in the 1960s, and China participated in several Afro-Asian conferences which took place in Africa. Gradually, the Sino-Soviet cleavage marked these conferences with its strong imprint. The Cultural Revolution in China and diverse interventions of the latter in Africa had produced a disastrous effect on the SinoAfrican relations, which nevertheless improved at the end of 1970s. The relations with China offered to African countries numerous advantages compared with those maintained with the western countries. In fact, China imposed fewer conditions in exchange for its assistance, granted loans with lower rates, and offered to train African workers for specialized tasks.

"The employment by the Westerns of conditionality ${ }^{2}$ echoes the humiliations resulting from "inequitable treaties" imposed on China by the Western in the XIX century. In reality, the capacity of China to recognize that fact comes from the genius of its African foreign policy",

From a political point of view, China gave priority to visible prestigious projects in Africa, such as stadiums and hospitals. For instance, China financed the construction of a railroad line between Zambia and Tanzania between 1973 and 1976, and sent some 15000 Chinese to work on this construction site, although this investment was beforehand rejected by the British authorities and the World Bank (Chaponnière, on 2008). It is striking that China brought such a development aid, as well as a military support, while it was sometimes even poorer than certain African countries. These activities probably incited countries having recently reached the independence to support the effort spread by China to obtain a permanent siege in the United Nations Security Council in 1971.

The relations of China with Africa evolved from the economic opening decreed by Deng Xiaoping ${ }^{4}$, and who marked a spectacular reversal compared with the politics followed under Mao. These relations stopped being dominated by ideological considerations. However, the official principles of the Chinese presence abroad, which includes equality between the partners, the mutual character of the advantages, the respect for the sovereignty, the recourse to grants and loans without interests, the building capacity in the profitable country, the respect for the obligations, the provision of the equipment made in China and the same living conditions for the Chinese and local experts, did not change (Larkin, on 1971; Chaponnière, on 2009). The sudden spark in interest of China in the African continent is a consequence of its increasing dependence of

2 The result of a long series of humiliating experiences seen during decades under the yoke of former colonial powers and the United States.

3 Alden, on 2007 , page 20

4 Deng Xiaoping was the General Secretary of the Chinese Communist Party (CCP) from 1956 till 1967 and later he became the president of People's Republic of China from 1978 till 1992. Although he retires from business, there was a referent for the regime until the death in 1992.
China on the energy (energetic inputs such as Oil) to fuel its economy.

The trade between China and Africa, which was small until 1954, has significantly increased in recent years. The increase in trade after the year 1954 was very steady and remains so until 1974, before the opening of China. The progressive liberalization of the Chinese economy as from 1978 came along with the development of trade with Africa, although Africa remained a marginal business partner for China compared with other continents (Europe, America, and Asia). However, starting from 2009 when China replaced the big European countries and the United States as first business partner of Africa, trade between China and Africa quadrupled in seven years. Between 2010 and 2011, Chinese-African trade went from 127 billion USD to 166.3 billion USD, and this was equivalent to trade between China and Germany.

Chinese trade ties reflect his political links: Soviet Union was its main trading partner till the beginning of 1960 s, date from which the Sino-Soviet bilateral trade collapsed, and China maintained no commercial relation with the United States between 1951 and the visit of President Nixon in China, in 1972. Although China's trade with Western Europe is fluctuating, since the 1960s Europe is the second trade partner of China, essentially thanks to Germany. The part of Asia was in progress until early 1960s, and represented a little more than half of Chinese trade today.

\section{Chinese Investments in Africa}

This section intends to see how Chinese Foreign Direct Investment in Africa appeared by sector from 1979 to 2000. Next, this section will look at the evolution of the flow Chinese FDI in Africa, since the first launch of the Forum on Sino-Africa Cooperation (FOCAC) 2000 until 2011.

The increase in the flow of capital over the years was stimulated by the development of the investment of the Chinese companies in diverse sectors. Chinese state ownedcompanies are encouraged to invest and to operate abroad. This is included in the objectives of China to search for strategic resources and market shares. Since early 2000, the presence of China is significant in Africa than in other continents. The State owned companies are at the heart of the global presence of China and made major breakthroughs in the overseas markets. If we assess it by the number of the Chinese companies represented in Global Forum $500^{5}$, the list of Chinese multinational companies is almost endless.

In 2009, 34 Chinese companies appeared among the largest companies, ranked between 9th and 489th. In 2011, we counted 57Chinese companies, with an improvement of the rank situated between 3th and 488th, with three companies ranked among first ten ones. In 2015 the antique hunting occupied the second place as well as the fourth place in the classification of Global Forum 500.

\footnotetext{
5 He allows giving a classification of 500 companies more important for the world in terms of turnover.
} 
Table of the Chinese foreign direct investment in Africa by sector, in million USD from 1979 to 2000.

\begin{tabular}{lll}
\hline Sector/industry & $\begin{array}{l}\text { Number of } \\
\text { projects }\end{array}$ & $\begin{array}{l}\text { Value of the investments } \\
\text { in million dollars USD }\end{array}$ \\
\hline Agriculture (Farming) & 22 & 48 \\
Extraction of the resources & 44 & 188 \\
Factory represented by: & 230 & 315 \\
1 Machines & 20 & 16 \\
2 Household electrical & 36 & 25 \\
appliances & & \\
3 light Industry & 82 & 87 \\
4 Textiles & 58 & 102 \\
5 Other industrial products & 34 & 86 \\
Services & 200 & 125 \\
Other & 3 & 6 \\
Total & 499 & 681 \\
\hline
\end{tabular}

Source: UNCTAD, on 2007

When we look at the table above, it is reported that before 2001, the Chinese foreign direct investments in Africa increased near to 681 million USD during the period of more than twenty years, (that is 1979 to 2000) for a total of 499 projects. These investments were largely centered in the manufacturing sector with a total of 230 projects for 315 million USD, and then came the mining industries with a total of 44 projects for 188 million USD, followed by the farming sector which was represented with 22 projects for 48 million USD.

However, the bilateral trade between China and Africa increased by more than $30 \%$ during eight years, exceeding 100 billion USD in 2008. After a light backward drop in 2009 because of the world financial crisis, the bilateral exchanges reached 127 billion USD in 2010, making China one of the main trade partners of Africa. In addition to the intensification of the trade ties encouraged by the proactive politics of the Chinese government, the investments of the Chinese companies in Africa increased in a considerable way. Today, undoubtedly, China carried out a breakthrough on the African continent. Beijing reunited almost all of the African States in its one-China principle and became for certain African countries an alternative of political cooperation. A decade only after the launch of the Forum on the Sino-African Cooperation (FOCAC), trade between China and Africa reached a record level of 166, 3 billion USD in 2011. China has become a major partner of the continent in terms of trade and financing of infrastructures projects.

The outgoing flows of FDI from China and managed towards Africa increased quickly over the period 2003-2008, but registered a significant reduction in 2009. The stock of Chinese investments in Africa reached 9, 3 billion USD at the end of 2009 , representing $3.8 \%$ of the total stock of FDI of China.

The main beneficiary of Chinese FDI in Africa is largely South Africa (which represents a quarter of the total of Chinese Foreign Direct Investments on African continent, followed by Nigeria (with 1,03 billion USD), Zambia, Algeria, Sudan, the Democratic Republic of the Congo, Egypt, Ethiopia, Tanzania and Maurice (for a global amount of 243 million USD).

Regarding the distribution of Chinese FDI in Africa, the lack of data limits any quantitative evaluation. The available information reveals a strong proportion of Foreign Direct Investments goes towards the mining industries, which is understandable owing to the effort to search for natural resources made by Chinese mining and oil companies. The total number of projects in other industries remains nevertheless important, and the current industrial restructuring in China could be translated by an increase of FDI in the sector of the industrial production in Africa.

\section{Literature Review}

Several authors have tried to list out the effects of the FDI. Their studies revealed that the effects of the FID are positive for some authors and negatives for others, as we can see it from the following authors:

1. Hermes and Lensink (2000), present different channels through which positive externalities caused by FDI, namely:

- Competition channel where increased completion is likely to increase productivity, efficiency and investment in human capital,

- Training channel: trough increased training of labour and management,

- Linkages channel: whereby foreign investment is often followed by technology transfer, which may take place through transactions with foreign firms

- -Domestic firms benefit: the more advanced technologies used by foreign firms, commonly termed as the demonstration channel.

2. According to Morisset (2000), analyses the impact of factors that determine FDI to Africa. According to the author, African countries can also be successful in attracting FDI that is not based on natural resources or the size of local markets but by improving their business climate. Using FDI that does not arise from market size and natural resource available in the host country as an indicator of business climate for FDI, the author finds that GDP growth rate and trade openness can be used to improve the business climate.

3. Asiedu (2006), analyses the relative influence of natural resources and market size in relation to government policy, host country's institutions and political instability in attracting FDI to Sub- Saharan Africa. The main finding is that countries that are endowed with six natural resources or large markets will attract more FDI. However, other factors like macroeconomic stability, educated labour force, good infrastructure openness to FDI, an efficient legal system, less corruption and political stability also promote FDI. According to the author, the findings suggest that small countries or countries with lack of natural resources in the region can also attract FDI by improving their institutions and policy environment. Pfefferman and Madarassy (1992), argue in favor of market size hypothesis and confirm 
that market size is one of the most important index in marking investment location decisions for three reasons: larger advantage for local sales the greater profitability of local sales than export sales and relatively diverse resources which make local sourcing more feasible. In other words, the market size is a determining factor which excites multinational firms so, markets with large populations tend to give multinational firms more opportunities to make profits and thus become more attractive to their investments.

4. Yin-Wong and al. (2010), examined the empirical determinant of China's outward direct investment in Africa. Using two data sets, a unique China's improved outward direct investment and a new outward direct investment data set in OECD-IMF standard; they identified some conventional determinants and discover some interesting results of China's outward direct investment activities in Africa. China's outward direct investment seeks the African market, invests more when the local currency is relatively cheap, and prefers to go to countries with better economic conditions.

5. Brewer (1991), empirically proved that there is a negative correlation between the economic growth and the FDI. Such a correlation is attributed to the effect of domination exercised by foreign firm which can discourage the local firm to develop his own activity of Research and development, what mean that the FDI can have a negative effect on the economic growth.

6. Blomström and Wang (1992), by studying the effect of the FDI on the growth, demonstrated that its scale depends on the stock of available human resources in the host country. They add that this impact can be negative in countries with a low level of human resources. The two authors argue that an increase in FDI leads to a rise in income, but this effect remains confined to the interaction between FDI and human resources. This has confirmed the idea that technology transfer cannot increase the growth rate of the host country, unless they interact with a certain absorption capacity of this one. Furthermore, they claimed that the contribution of the FDI to the growth arises when the interaction between the human resources and the FDI occurs (Alaya, 2004).

7. Besides, by using a function of neo-classic production, Saltz (1992) found a negative correlation between the level of the FDI and the economic growth. According to the author, the FDI increase the global level of the investment, in some case improves the productivity but in many others cases it tends to reduce the growth rate. To confirm his conclusions, he studied the relationship between FDI and the growth rate of several countries divided into two groups, depending on whether they received high or low FDI. He concludes that the correlation between FDI and growth rate is always negative in developing countries. This removes any constraint in the repatriation of profits associated to the FDI. The author states that, if the FDI is translated by a fundraising of the capital market of the host country, this would imply a redistribution of capital of the labour-intensive industries towards capital-intensive industries, creating therefore, a net job losses and consequently the consumption demand. Another negative effect of the Foreign Direct Investment can result from the excessive extraction of ores or the concentration on the production of particular goods which would lead to the price drop in the export and the deterioration in the exchange terms of the host country (Alaya, 2004).

It is however, obvious that the Foreign Direct Investment contributes to the economic development. Countries are advised to focus on the implementation of reliable measures in order to take full advantages of it.

\section{Effects of Chinese FDI in Africa}

The increase of the Chinese FDI in Africa was very remarkable over the years, but this increase produced two effects (positive and negative) on the African continent. As we previously described, many economists often have diverging opinions concerning the effects of the FDI on the African economy. Nevertheless, Chinese FDI in Africa is not carried out in bad faith, like most of the Africa traditional partners think. Indeed, this one requires simply a good understanding and orientation so that both parties can as much as possible take full advantages of it.

That's why, it is important to look at the effects (positive and negative) of Chinese FDI in Africa in order to know what result from it. However, first of all, it would be necessary to present the model of Chinese investment in Africa.

\subsection{Chinese Investment Model in Africa}

The financing of the Chinese FDI in Africa is done through several State agencies, which are mainly represented by:

- China Export-Import Bank (China Exim Bank) created in 1994 to promote the development of the Chinese FDI, especially in the sector of infrastructures: Dams, railroads, roads, telecommunications, mining infrastructures, etc.

- China Development Bank (CDB) ${ }^{6}$ created in 1994 to provide financial support for commercial initiatives of Chinese companies both at national and international levels. She launched a China-Africa Development Fund, which is a platform for financing and Chinese foreign direct investments in Africa.

- China export and credit insurance corporation (SINOSURE) has provided insurance against the risks involved in Chinese export and foreign investment since 2001.

6 The Chinese purchased in particular of about $20 \%$ the capital of Standard, first African bank and China Development Bank sealed an alliance with the Union Bank of Africa, one of the main Banks of Nigeria. 
- China Investment Corporation (CIC) created in 2007, it is a sovereign fund for the development of the FDI.

The Chinese presence in Africa also involves a broad range of private sector, including multinationals, small businesses, traders, and migrants as well as Chinese local governments which at times act directly through the firms they own (Chen and Jian, 2009). There are several factors that make the relationship between China and Africa remarkable. We should keep in mind that Chinese model of investment and infrastructure loans is known as the Beijing consensus and it is a very important approach that needs to be discussed. As said by Ramos (2004) "it is a new attitude towards politics, development and global balance of power". Wenping (2007) said that it values the political and international relations concepts of multilateralism, consensus and peaceful co-existence. This approach is quite different with the so-called Washington consensus, a neo-liberal paradigm that lay great stress on democracy, good governance and poverty reduction (Fine and Jono, 2005).

Africa needs help to finance its investments (in infrastructures, hospitals, schools, communications, etc.), and the model of Chinese investment allow to reach this goal and improves the economic growth. And in return China takes advantage of it to exploit the raw materials which it needs to ensure its need growing in energy.

\subsection{The Positive Effects of Chinese Investment in Africa}

Since 2000, Chinese investments in Africa have been beneficial and positive in some aspects that we can elucidate as follow:

- In terms of economic development and economic growth in African countries, the positive effects are visible, for the increase of Chinese demand Chinese for raw materials prices allowed the improvement of trade and export incomes. The new Sino-African relations contributed to reintroduce Africa in the international flows of the formal trade from which it was aside for several decades. This increase in the oil incomes enabled some African countries to implement public or economic policies (structural adjustment) ${ }^{7}$.

Chinese FDI have improved economic growth in many African countries, because since a decade Africa's growth is $5 \%$ on average per annum, which has placed the continent among the most dynamic regions of the world. For example, in 2012 the growth of sub-Saharan Africa countries had increased more than $5.4 \%$ compared to the year 2011, which was $4.9 \%$. It should also be noted that in 2013 , South Africa had been among the top 30 (the most powerful economies in the world), and ranked the twenty-ninth in world.

- In terms of infrastructure development, Chinese investment in Africa has led to a remarkable improvement of this sector. The development of a given country must also go through the development of basic infrastructure (hospitals, hydroelectric dams, roads,

7 A structural adjustment: in the context of the reduction of unemployment, inflation and budget deficit. bridge, and so on), unfortunately during several years this was what most African countries lacked. But in recent years, much progress has been made in this direction, and over years African continent is equipped with basic infrastructure. For instance, the construction of the national road connecting the two main cities of the Republic of Congo (i.e. Brazzaville and Pointe Noire) whose the inauguration took place at the beginning of the year 2016, the construction of a major hospital in Luanda (Angola's capital city), stadiums built in Sierra Leone, airports and many other administration buildings in most countries which are recipient of these investments, etc.

All these achievement gave to African countries a new status of modernity and improvement of basic infrastructure that they lacked in the past. It should also be noted that in December 2011, China made a donation to Africa by building the new headquarters of the African Union (AU), located at Addis Ababa in Ethiopia, which had cost more than 200 million USD.

- In terms of social development, it can be said that Chinese investments have brought their results. First, the increase of Chinese investments in Africa has resulted in competition between Chinese investors and traditional investors (i.e. Europe and America), and the local population benefited from it. In other words, this competition drove traditional investors to increase the salaries of some employees, and signed employment contracts, since some employees were hired without an employment contract, for fear of losing their employees who may be tempted by the massive coming of Chinese investments.

Secondly, Chinese FDI helped Chinese products to take an important place on the continent, and this has led to an improvement of the living conditions of local populations. Indeed, Chinese product, i.e. "made in China" are increasingly in all stores in Africa, and thanks to these products Africans have had easy access to products that were considered some time ago as luxury products, such as: mobile phones, computers, air conditioners, etc., their low prices have therefore improved the purchasing power of consumers. Chinese investment enabled African population to have easy access to the products of malaria (regarded as a scourge on the African continent), reducing thereby the mortality rate caused by the latter.

Thirdly, Chinese investment in the agricultural sector, allowed some African countries to reduce prices of food, contributing to the improvement of the shopping basket of consumers and the reduction of famine.

- On the education and culture level, Chinese investments in Africa are also beneficial. At the education level, significant progress has been made, because after the FOCAC meeting of 2006, Chinese Government had increased the number of scholarship which he used to allocate to African students, and so far this increase has continued, and that also involved the training of military officials. 
With regard to culture, African people are increasingly interested in Chinese culture, and many Chinese language learning centers were established throughout the continent and in some countries Governments have introduced the Chinese language in the school program.

Finally, Chinese leaders as well as African ones seem completely convinced of the mutual profits which their countries pull of this cooperation. Whereas Africa benefits from the development of long-term infrastructures, China enjoys an access to the oil and to the numerous natural resources of the continent, what allows him to feed its branch of rapidly expanding industry.

However, it is important to underline that beyond all these positive effects of Chinese investment in Africa, there also seems to be negative effects that are harmful to the continent. Reason why we need to treat with extreme caution Chinese investment in Africa.

\subsection{The Negative Effects of Chinese Investment in Africa}

Chinese investment in Africa, were not only beneficial as it seems to be suggested by the Chinese and African Governments, on the contrary these investments have been accompanied by several negative effects on the African continent that we might present as follows:

- In the economic sector, we can say that the increase of Chinese investment in Africa has negatively affected local companies. Many Africans have denounced the poor quality of Chinese products and estimated that their low price is the cause of the collapse of local industries. Ademola and al. (2009) quote several examples of country where companies are threatened by the Chinese imports, what leads to numerous closures. In the textile industry, South Africa apparently lost between 23000 and 85000 jobs. In Ghana also, companies have to close. Furthermore, the competition in this sector caused the slowing down of the interAfrican trade, because countries such as South Africa, Cameroon, Kenya and Madagascar lose market shares in nearby countries due to the massive penetration of Chinese clothing on the continent. A study dedicated to the effect of eviction produced by the Chinese exports highlights the link between the progress of the Chinese textiles exports (textile industries) and the backward movement of the African exports (Giovannetti and Sanfilippo, on 2009). Generally speaking, in the sectors where China and Africa are in competition, the increase of the Chinese exports leads to a reduction in African production.

The increase of Sino-African trade often comes along with trade imbalance to the advantage of China. It is particularly the case for South Africa and Nigeria which present respectively a trade deficit towards China of 4 billion and 1.7 billion USD. Indeed, Sino-African economic relations are represented in the form of North-South trade (as the North, China seeks to secure its access to raw materials) and therefore constitutes a serious handicap for African continent, which continues to play the role of provider of raw materials (oil, wood, cantons, etc.), weakening thereby its position in the international division of labour.

We shall also note that Chinese investors hire essentially Chinese workers who represented a total of $70 \%$ against a total of $30 \%$ of local workers. This is a real concern for Africans, because for the most part of them the only interest of these foreign investments is that they create some employment. Thus, the massive hiring of Chinese workers is not favorably appreciated.

- Socially, Chinese FDI in Africa are a serious problem. As a matter of fact, the social rights of African workers hired by Chinese enterprises are constantly violated (underpaid, non-compliance with labour standards, nonrecognition of trade unions, etc.), and Chinese companies do not take much social responsibility as their western counterpart do.

- Concerning the environment protection, Chinese investments are also a problem. Environmental standards are not really respected by Chinese companies, because they give more importance to the quest of raw materials and the implementation of infrastructure projects (roads, bridges, railways, dams, etc.) than to environment concerns. Most of international standards in the construction of bridges, dams are not fully respected for the sole purpose of making more profits. It should also be noted that most of the time Chinese companies specializing in logging do not respect international standards in this sector of activity, leading therefore to the illegal sale of wood.

\section{Conclusion and Future Prospects}

\subsection{Conclusion}

As described throughout in this article, we can say that the emergence of the Chinese economy since 2000, accompanied by a strong growth of Chinese FDI in Africa, has produced both positive and negative effects on that continent. On the one hand, they have enabled African countries to improve the well-being of their populations, and to experience economic development and economic growth. On the other hand, these investments have also some obvious negative effects, such as the collapse of some local industries, the non-compliance with environmental standards by Chinese companies more focused on the raw materials and the construction of infrastructure, and the disregard of labour standards concerning local workers.

Thus, it seems clear that Chinese FDI in Africa hide a form of neocolonialism. These investments are seen by Westerners as being motivated by the quest of the raw materials of African countries, and not as a contribution for the development of the African continent.

Nevertheless, it can be acknowledged that the entry of financial and human flows from China generates mutual short-term advantages and can stress complementarities between China and Africa. However, if they want to gain all 
the profits of this cooperation (that is China's Foreign Direct Investment in Africa), African countries will have to strengthen their political institutions and better their public governance. The consolidation of the institutions and the good governance should produce a beneficial effect on the implementation of social measures and environmental protection, while encouraging the hiring of African local workers in biggest investment projects performed on the continent.

These rules would apply not only to Chinese investors, but also to all the investors of the other countries, according to the agreement of the World Trade Organization so that all investments done in Africa might fully contribute to its development and eradicate poverty.

\subsection{Future Prospects}

The current state of the global economy (falling prices of the barrel of Oil), and the negative growth experienced the Chinese economy might likely in a near future lead to a reduction in Chinese FDI in Africa. Indeed, since few years Chinese government increased its FDI in Africa, and these investments come along with a strong economic growth in the continent due to the export of oil towards China. But since $2014^{8}$, we began to witness a strong down fall of that price, although a light increase was observed in spring, 2015 (60 dollars / barrel in May), the price downfall restarted at the end of the summer. The West Texas Intermediate (WTI) fell under the bar of 40 USD / BARREL at the end of August, 2015, and later passed on September 9th in 45 USD / BARREL. Today the Oil price varies between 30 and 40 USD/BARREL.

Nevertheless, we know that most of African countries have experienced fast growth rate in recent years owing to the massive Chinese investments on the continent. We may say that, if some countries of Africa have experienced strong economic growth today, it is largely thanks to Chinese investments.

However, the drop of Chinese economic growth will possibly affect the economic growth of African countries, which will lead to a strong reduction in the months or years to come of Chinese FDI on Africa continent. That situation in turn will result in the slowing down of African economy.

\section{References}

[1] Ademola, O., Bankole and Adewuyi A. O (2009), "ChinaAfrica trade relation: insight from AERC Scoping Studies", European Journal of development research, A. O Vol. 21, № 4, PP. 485-505.

[2] Alaya, M. (2004), «L'Investissement Direct Etranger contribue-t-il réellement à la croissance économique des pays

8 On the American market, West Texas Intermediate (WTI) side in New York Mercantile Exchange (NYMEX, the stock exchange of the raw materials of the financial center of New York) and the price of which serves as reference for the fixation of the price of the crude oil so passed of 107 USD / BARREL in the end of June, 2014 in 45 USD / BARREL in January, 2015. du Sud et de l'Est de la méditerranée?», C. E. D, Université Montesquieu-Bordeaux IV.

[3] Alden, C. (2007) China in Africa, David Phillip, South Africa and zed Books Ltd, London and New-york, 157p.

[4] Asiedu E (2006). "Foreign Direct Investment in Africa: the role of natural resources, market size, government policy, institution and political stability" World economy 29 (1): 6377.

[5] Blomström M and Wang H (1992), "Foreign investment and technology transfer", European Economic Review, Volume 36, Issue (3), Juin (1992), pp 45-70.

[6] Brewer T. L., (1991), "Foreign Direct Investment In developing Countries: Patterns, policies, and prospects" PRE Working paper № 34.

[7] Chaponnière, JR (2008) «Un demi siècle de relation ChineAfrique. Evolution des analyses" ("A Half-Century of SinoAfrican Relation: Trend and Analysis"), Afrique Contemporaine, Vol. 4 № 228, pp. 35-48.

[8] Chaponnière, J. R (2009) "La dérive des continents: l'Asie et l'Afrique" («The drift of continents: Asia and Africa"), № 350 mars 2009, pp. 5-26.

[9] Chen Z and Jian J (2009). "Chinese provinces as foreign policy actors in Africa”, occasional paper № 22, South African institute of international affairs, Johannesburg.

[10] Fine B and Jomo KS (2009) in Sautman, B and Hairong. Y (2007). "Friends and Interests: China's distinctive links with Africa", African studies review, 50 (3): 75-115.

[11] Gaye Adama, (2006), Chine-Afrique; le dragon et l'Autriche, Coll. Etudes Africaine, Paris, Harmattan, 286p.

[12] Giovannetti, G. and Sanfilippo, M. (2009) "Do Chinese exports Crowd-out African Goods? An Econometric Analysis by country and sector", The European Journal of Development Research Vol. 21, № 4, pp. 506-530.

[13] Hermes N and Lensink R (2000). "Foreign direct investment, financial development and economic growth". SOM Research report 00E27. University of Groningen, the Netherlands

[14] Larkin, BD. (1971) China and Africa, 1949-1970: "The Foreign Policy of the People's Republic of China" California University Press, 266p.

[15] Loots E (2009). "Foreign direct investment to Africa: Trends, dynamics and Challenges. Paper presented at the sixth African finance journal conference: Research and development in development finance". Cape Town, 16 and 17 July.

[16] Morisset J (2000). "Foreign Direct Investment in Africa: Policies also Matter". Transnational corporations 9 (2): 107253.

[17] Pfefferman GP and Madarassy A (1992). "Trends in private Investment in developing countries, international finance corporation, and discussion" paper N0. 14. Washington D. C

[18] Ramos JC (2004). "The Beijing Consensus". The Mezzanine Elisabeth House. String information services; the foreign policy centre, 1-79.

[19] Richer, Ph. (2008) "L'offensive Chinoise en Afrique (Then Chinese offensive in Africa)", Karthala Paris. 
[20] Saltz, I. (1992). "The Negative Correlation between Foreign Direct Investment and Economic Growth in the Third World: Theory and Evidence," Rivista Internazionale di Scienze Economiche e Commerciali Vol. 39, pp. 617-633, July.

[21] Wenping H (2007). "The balancing act of China's African Policy”. China security, 3: 23-40.

[22] Yin-Wong Cheung, Xing Wang Qian and Shu Yu (2010), "China's Outward Direct Investment in Africa" available at http//www.hkimr.org/uploads/publication/66/ub full 02277 wp; № 13 2011-final.pdf.
[23] Zafar A (2007). "The growing relationship between China and Sub-Saharan Africa: macroeconomic, trade, investment and aid links". Oxford j Economics \&social sciences, World Bank research observer, 22 (1): 103-130.

[24] Zhibiao L. (2007), "Contemporary Economic and Trade Relations between China and Africa", in Prah K. K. (Ed). Afro-Chinese Relations: Past, Present and Future, Cape Town, the Centre for Advanced Studies of African Society. 